УДК 94(477.83) «1941-1944»

DOI 10.24919/2519-058X.5.116974

Богдан ЛАЗОРАК,

orcid.org/0000-0002-1551-2629

директор КЗ ЛОР «Державний історико-культурний заповідник «Нагуєвичі», кандидат історичних наук, доцент кафедри історії Украӥни Дрогобицького держсавного педагогічного університету імені Івана Франка (Україна, Дрогобич) istoryk_@ukr.net

\title{
БАНКІВСЬКА СПРАВА ДРОГОБИЧА У 1919 - 1939 рр. ТА ОСОБЛИВОСТІ РИНКУ КАПІТАЛОВКЛАДЕНЬ НАЦІОНАЛЬНИХ ГРОМАД*
}

У статті аналізується прочес інституиійного розвитку банківських установ Дрогобича у період після завершення польсько-украӥнської війни, аж до початку буремних подій «вересня 1939 р.». Встановлено, щзо за иеей короткий проміжок часу у Дрогобичі польською владою було організовано дієву систему приватних та державних банків, які в основному зосереджували у собі капітал польських та єврейських банкірів, натомість український капітал мав спорадичний баланс у цій системі, і навіть почасти окремі обмеження. 3 іншого боку, Дрогобич серед багатьох провіниійних міст Галичини обіймав друге місие після Львова за рухом коштів та розмаїтістю банківських установ. Відтак реконструюється коротка історія розвитку банків «столиці Галицької Каліфорнії».

Ключові слова: Дрогобич, банк, гроші, нафтова промисловість, злотий, філія.

Jim. 12.

Bohdan LAZORAK,

Director of State Historical and Cultural Reservation «Nahuievychi» Ph D (History), Associate Professor of Ukraine's History Department of Drohobych Ivan Franko State Pedagogical University (Ukraine,Drohobych) istoryk_@ukr.net

\section{BANKING BUSINESS OF DROHOBYCH IN 1919 - 1939 AND THE PECULIARITIES OF THE INVESTMENT MARKET OF THE NATIONAL COMMUNITIES}

The article analyzes the process of institutional development of Drohobych 'banking establishments in the period after the end of the Polish-Ukrainian war, until the start of the stormy events of September 1939. It is established that in Drohobych, during this short period of time, the Polish authorities organized an efficient system of private and state banks that concentrated the capital mainly of Polish and Jewish bankers, whereas the Ukrainian capital had a sporadic balance in that system and, though partialy, even some restrictions. On the other hand, of many provincial cities of Galicia Drohobych occupied the second place after Lviv due to the movement of funds and diversity of banking institutions. Thus, a brief history of the development of the banks of "Galician California's capital» has been reconstructed in the article.

Key words: Drohobych, bank, money, petroleum industry, zloty, branch office.

Ref. 12.

Богдан ЛАЗОРАК, директор КЗ ЛОР «Государственный историко-культурный заповедник« Нагуевичи», кандидат исторических наук, доцент кафедры истории Украины Дрогобычского государственного педагогического университета имени Ивана Франко (Украина, Дрогобыч) istoryk_@ukr.net

\section{БАНКОВСКОЕ ДЕЛО ДРОГОБЫЧА В 1919 - 1939 ГГ. И ОСОБЕННОСТИ РЫНКА КАПИТАЛОВЛОЖЕНИЙ НАЦИОНАЛЬНЫХ ОБЩИН}

В статье анализируется процесс институционального развития банковских учреждений Дрогобыча в период после завершения польско-украинской войны, вплоть до начала бурных событий “Сентября 1939». Установлено, что за этот короткий промежуток времени в Дрогобыче польскими властями было орга-

\footnotetext{
* Публікація містить результати досліджень, проведених у рамках виконання наукового проекту «Українсько-польсько-єврейські взаємини у Східній Галичині (перша половина XX ст.): історичний досвід, уроки для сучасності». ID:95861 29.08.2017 (176-1)
} 
низовано прочную систему частных и государственных банков, которые в основном сосредоточивали в себе капитал польских и еврейских банкиров, зато украинский капитал имел спорадический баланс в этой системе, а также отчасти отдельные ограничения. С другой стороны Дрогобыч среди многих провинцииальных городов Галичины занимал второе место после Львова за движением средств и разнообразием банковских учреждений. Поэтому реконструируется краткая история развития банков «столицы Галицкой Калифорнии».

Ключевые слова: Дрогобыч, банк, деньги, нефтяная промышленность, злотый, филиал.

Лиm. 12.

Постановка проблеми. Дослідження історії банківської справи Дрогобича міжвоєнного періоду історії Галичини дає змогу простежити не тільки процес становлення польського та єврейського капіталу, але й реконструювати структуру програми державного контролю за обігом злотого як валюти Другої Речі Посполитої. 3 іншого боку, вивчення палітри філій та стаціонарних приватних банків міста Дрогобича полегшує дослідження історії нафтової промисловості міста, а також його стратегічне значення в економіці польської держави. Водночас на грунті інституційного розвитку банків Дрогобича можна визначити його характер за національним складом та стилем капіталовкладень

Аналіз досліджень. Варто зауважити, що в українській історіографії Незалежної України тема банківської справи в Дрогобичі практично не вивчалася, натомість більшість праць, присвячених цій темі, були студійовані польськими істориками та властиво довідниковими розвідками міжвоєнної доби, які сьогодні є частиною спеціальної літератури у даній статті.

Виклад основного матеріалу. Після завершення польсько-української війни 1918 - 1919 pp. у Дрогобичі банківська справа почала переходити на ритм жорсткого контролю з боку уряду Другої Речі Посполитої, врешті було ліквідовано усі українські фінансові інституції часів ЗУНР. Одним із найбільш стабільних у Дрогобичі в період реанімації нафтового бізнесу виявилося «Бюро із продажу продуктів державних нафтопереробних фабрик» («Biuro Sprzedaży Produktów Państwowej Fabryki Olejów Mineralnych w Drohobyczu») [10].

У 1921 р. ситуація почала змінюватися на краще, адже кілька банківських інституцій зуміли організувати на період повоєнної відбудови «Дрогобицький банківський союз», який був зареєстрований як Товариство з обмеженою відповідальністю. У ситуації повоєнної розрухи економіки та валютної нестабільності відновленого польського злотого спільний союз дозволяв швидко приймати спільні та координовані рішення, для унеможливлення кризових явищ, пов'язаних із несприятливим кліматом у конкуренції. Так, до числа союзу увійшли: Відділення «Варшавського банку для торгівлі та промисловості» («Bank dla Handlu i Przemysu w Warszawie»), «Ексконтний та депозитний банк», який мав статус союзу двох банків із обмеженою відповідальністю («Bank Eskontowy i Depozytowy»), Відділення «Варшавського дисконтного банку» («Bank Dyskontowy Warszawski»), а також Відділення «Варшавського кредитного банку» («Bank Kredytowy w Warszawie»). Натомість відділення «Польського торгівельного банку» («Polski Bank Handlowy») та філія «Польського промислового банку» («Polski Bank Przemysłowy») вирішили працювати окремо від союзу. У цьому ж році в Дрогобичі вийшла на ринок цінних паперів Торгівельно-промислова акціонерна спілка «Elibor», відділення котрого реєструвало контракти про кредитування в найрізноманітніших сферах дрібного та великого бізнесу. Також окремі послуги пропонувала фінансова спілка із обмеженою відповідальністю під назвою «Галицька торгівельна спілка для технічних справ». На ниві заощаджень та вигідних відсоткових ставок відновлювала роботу давня «Ощадна каса» Дрогобича. Натомість дрогобицькі купці утворили власне «Кредитне купецьке товариство», яке також мало права з обмеженою відповідальністю. Багаті міщани Дрогобича вирішили у 1921 р. об’єднати свої фінансові справи під захистом власного товариства, яке отримало назву «Міщанське кредитне товариство Дрогобича» («Mieszczańskie Towarzystwo Kredytowe w Drohobyczu»), яке так само отримало обмежені права. Давній «Віденський федеральний банк» («Wiedeński Bank Związkowy») також не був ліквідований, позаяк польські активи продовжували ще залишатися у Відні на залишках, а тому співпраця була необхідною. Від імені цього банку в Дрогобичі працював Рубін Вальд, який був відомим віденським купцем, а також представником від «Торгівельного товариства» в Дрогобичі $[10,66-68,102]$. 
У 1922 р. у Дрогобичі було відкрито відділення «Польського крайового банку», який вів свою традицію від колишнього австрійського «Крайового банку для Королівства Галичини та Лодомерії з великим Краківським князівством» («Bank Krajowy dla Królestwa Galicji i Lodomerii z Wielkim Księstwem Krakowskim»). Банк був центральною кредитною інституцією АвстроУгорщини. Час його фундації припадає на 1881 р. у Львові. Фактична діяльність банка розпочалася у 1883 р. Спочатку головна функція полягала у наданні довготривалих кредитів для селян, але, починаючи від 1891 р., банк починає системно фінансувати промислові інвестиції, зокрема у сфері залізниці та міського комунального господарства. Грунтовну монографію з історії цього банку написав М. Бен-Джозеф у Кракові [3]. Також див. докладніше статут цього банку утверджений 21 червня 1882 р. [11] У 1924 р. цей банк разом із «Державним банком відбудови і кредитної спілки малопольських міст» увійшов до складу «Банку крайового господарства», яким почав керувати Ян Стечковський. У час «Великої депресії» цей банк успішно керував Дрогобицькою філією, адже зумів обмежити розміри своїх ставок, залишивши вкладення винятково у прибуткових нафтових гірничих проектах. Щоправда, рятівна кампанія над акціями банкрутуючих фірм у 1925 р. не принесла очікуваних результатів. Проте вже 3 другої половини 30-х рр. ХХ ст. цей банк у Дрогобичі став головним кредитором для реалізації інвестицій, обійнявши перше місце в Центральному Промисловому окрузі. Цілком невипадково станом на 1928 р. загальний капітал банку задекларував у Варшаві 130000000 злотих [5, 41, 45-46].

У січні 1924 р. досить таки потужні позиції у банківській конкуренції Дрогобича посідало відділення «Варшавського банку для торгівлі та промисловості» [2].

Загалом, у міжвоєнний період у Дрогобичі продовжували діяти приватні та державні банки, а також кредитні страхові спілки банківського статусу. Найбільш потужними вважалися: 1) «Польський промисловий банк» по вул. Міцкевича, 22 [6]; 2) «Польський банк» («Bank Polski») по вул. Міцкевича, 1 у колишньому будинку філії «Австро-угорського банку» (сьогодні будинок податкової інспекції м. Дрогобич); 3) «Банк крайового господарства» («Bank Gospodarstwa krajowego») на площі Бартоломія у колишньому будинку «Авансовогоого товариства»/«Towarzystwa zaliczkowego»); 4) «Соціальна страхова компанія» «Ubezpieczalnia Społeczna» на вул. Соляній (Сольній).

Згідно телефонних довідників 1930-х рр. у Дрогобичі діяло 8 великих банківських інституцій: державні та приватні банки, а також ощадно-кредитні спілки та товариства (див. тал. № 3). Їхня кількість, безумовно, перевищувала кількість подібних інституцій на початку 20-х рр. ХХ ст., оскільки фінансовий клімат Другої Речі Посполитої після світової економічної кризи 1929 1933 рр. серйозно змінився у зв'язку із пожвавленням конкуренції між світовими банками.

Таблиця № 3

Ресстр банків та ощадно-кредитних спілок і товариств м. Дрогобича у 1932 - 1938 рр.

\begin{tabular}{|c|c|c|c|}
\hline $\begin{array}{l}\text { № } \\
\text { II/II }\end{array}$ & Назва інституції & Адреса & Примітка \\
\hline \multicolumn{4}{|c|}{ Згідно з телефонною книгою 1932 - 1933 рр. [8] } \\
\hline 1. & $\begin{array}{l}\text { «Варшаський дискаунтерний банк» } \\
\text { /«Bank Dyskontny Warszawski») }\end{array}$ & вул. Міцкевича, 5 & $\begin{array}{l}\text { Відділення проводило торги цінними па- } \\
\text { перами за зниженими цінами }\end{array}$ \\
\hline 2. & $\begin{array}{l}\text { «Банк крайового господарства» } \\
\text { («Bank Gospodarstwa krajowego» }\end{array}$ & площа Бартоломія, 3 & $\begin{array}{l}\text { приміщення разом із житлом директора } \\
\text { пана 3. Ямпрунєвіча (директор також мав } \\
\text { помешкання за адресою вул. Св. Яна, 23) }\end{array}$ \\
\hline 3. & \begin{tabular}{|lcr} 
«Банк купців & i & промис- \\
ловців»/«Bank & Kupcyw i \\
Przemysłowców» & &
\end{tabular} & вул. Жупна, 3 & - \\
\hline 4. & «Польський банк»/«Bank Polski» & вул. Міцкевича, 1 & - \\
\hline 5. & $\begin{array}{l}\text { «Універсальний } \quad \text { федераль- } \\
\text { ний банк»/«Powszechny Bank } \\
\text { Związkowy» }\end{array}$ & $\begin{array}{l}\text { Площа ринок, } 17, \text { a } \\
\text { кабінет директора по } \\
\text { вул. Міцкевича, } 1\end{array}$ & $\begin{array}{l}\text { Відкрито у } 1923 \text { р. У } 1932 \text { р. директором } \\
\text { працював Саломон Вахс, який проживав за } \\
\text { адресою вул. Стрийська, 41. Заступником } \\
\text { директора працював пан Арнольд Пастор, } \\
\text { який мешкав за адресою: Св. Яна, } 41 .\end{array}$ \\
\hline
\end{tabular}




\begin{tabular}{|c|c|c|c|}
\hline 6. & $\begin{array}{l}\text { «Фундуш для безробітніх» (бір- } \\
\text { жова спілка) }\end{array}$ & вул. Св. Хреста, 7 & - \\
\hline 7. & Ломбард пана Юзефа Гуллеса & вул. Міцкевича, 23 & $\begin{array}{l}\text { приватна кредитна та лихварська органі- } \\
\text { зація }\end{array}$ \\
\hline 8. & $\begin{array}{l}\text { Кредитна кооперація «Народний } \\
\text { Дім» }\end{array}$ & вул. Пілсудського, 12 & українська кредитна спілка \\
\hline \multicolumn{4}{|c|}{ Згідно з телефонною книгою 1938 р. [9] } \\
\hline 1. & $\begin{array}{l}\text { «Варшаський дискаунтерний банк» } \\
\text { /«Bank Dyskontny Warszawski» }\end{array}$ & вул. Міцкевича, 5 (3?) & відділення \\
\hline 2. & $\begin{array}{l}\text { «Банк крайового господарства» } \\
\text { («Bank Gospodarstwa krajowego» }\end{array}$ & площа Бартоломея, 3 & - \\
\hline 3. & \begin{tabular}{|lcr} 
«Банк купців & i & \multicolumn{2}{c}{ промис- } \\
ловців»/«Bank & Kupców \\
Przemysłowców» & &
\end{tabular} & вул. Жупна, 3 & - \\
\hline 4. & «Польський банк»/«Bank Polski»» & $\begin{array}{l}\text { вул. Міцкевича, } 1 \text { (ко- } \\
\text { лишній будинок «Ав- } \\
\text { стро-Угорського бан- } \\
\text { ку»). }\end{array}$ & $\begin{array}{l}\text { Навесні } 1939 \text { р. будинок банку було під- } \\
\text { дано серйозній реставрації; директор } \\
\text { проживав також у цьому будинку; від } \\
1938 \text { р. скарбником банку, а від вересня } \\
1939 \text { р. директором працював батько Єжи } \\
\text { Пілєцького - Здіслав Пілєцький, якому } \\
\text { було виділено житло на вул. Бартоломея, } \\
14 \text { (сьогодні Нижанківського) [12] }\end{array}$ \\
\hline 5. & $\begin{array}{l}\text { «Універсальний } \\
\text { ний банк» /«Powszechny Bank } \\
\text { Związkowy» }\end{array}$ & $\begin{array}{l}\text { Площа ринок у будин- } \\
\text { ку ратуші разом із ка- } \\
\text { бінетами дирекції }\end{array}$ & $\begin{array}{l}\text { Відділення відкрито у Дрогобичі в } 1923 \\
\text { р. У } 1938 \text { р. директором працював Зиг- } \\
\text { мунд Альтман, який проживав за адре- } \\
\text { сою: вул. Міцкевича, } 25 .\end{array}$ \\
\hline 6. & $\begin{array}{l}\text { «Кооперативний банк поль- } \\
\text { ських ремісників та промислов- } \\
\text { ців»/«Bank Spółdzielczy polskich } \\
\text { rękodzielników i przemysłowców» }\end{array}$ & вул. Міцкевича, 22 & $\begin{array}{l}\text { Основні фінансові операції стосувалися } \\
\text { підтримки дрібно та середнього бізнесу, } \\
\text { зокрема дрібних ремісників: м'ясників, } \\
\text { шевців, ковалів, а також різноманітних } \\
\text { м'ясо-молочних кооперацій дрогобиць- } \\
\text { кого повіту, тощо. }\end{array}$ \\
\hline 7. & $\begin{array}{l}\text { «Ощадна каса міста Дрогоби- } \\
\text { ча»/«Kasa Oszczędności miasta } \\
\text { Drohobycza» }\end{array}$ & $\begin{array}{l}\text { Площа ринок, примі- } \\
\text { щення ратуші (3 боку } \\
\text { теперішнього «соцбе- } \\
\text { зу») }\end{array}$ & - \\
\hline 8. & $\begin{array}{l}\text { «Повітова комунальна ощадна ка- } \\
\text { са»/«Kasa Oszczędności Powiatowa } \\
\text { Komunalna» }\end{array}$ & 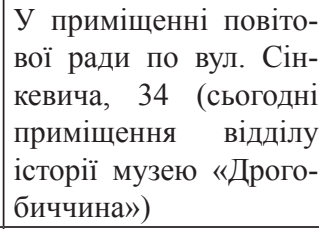 & - \\
\hline 9. & $\begin{array}{l}\text { «Каса Першого Податково- } \\
\text { го Управління»/«Kasa I Urzędu } \\
\text { Skarbowego» }\end{array}$ & $\begin{array}{l}\text { У приміщення подат- } \\
\text { кового управління }\end{array}$ & - \\
\hline 10. & $\begin{array}{l}\text { «Купецька кредитна коопера- } \\
\text { ція»/«Kupiecka Spółdzielnia } \\
\text { Kredytowa» }\end{array}$ & вул. Пілсудського, 8 & - \\
\hline 11. & $\begin{array}{l}\text { Кредитна кооперація «Народний } \\
\text { Дім» }\end{array}$ & вул. Пілсудського, 12 & Українська кредитна кооперація \\
\hline 12. & $\begin{array}{l}\text { Український «Господарсько-спо- } \\
\text { живчий повітовий союз») }\end{array}$ & $\begin{array}{l}\text { Площа Смолки (як } \\
\text { складова організація } \\
\text { «Народного дому») }\end{array}$ & - \\
\hline
\end{tabular}




\begin{tabular}{|c|c|c|c|}
\hline 13. & $\begin{array}{l}\text { «Повітова каса } \quad \text { для } \\
\text { рих»/«Powiatpwa } \\
\text { Chorych» }\end{array}$ & - & $\begin{array}{l}\text { Громадська страхова компанія; у } 1922 \text { р. } \\
\text { на посаді лікаря інспекторати цієї каси } \\
\text { працював відомий учасник I Світоої } \\
\text { війни майор Едвард Мізюра (1887 - } \\
+1955 \text { рр.) }\end{array}$ \\
\hline 14. & $\begin{array}{l}\text { «Громадська страхова компанія» } \\
\text { /«Ubezpieczalnia Społeczna» }\end{array}$ & $\begin{array}{l}\text { вул. Раймунда Яроша, } \\
2\end{array}$ & $\begin{array}{l}\text { У приміщенні діяли секретаріат, фінансо- } \\
\text { вий відділ, секція обмірів, склад, секція } \\
\text { податків, референція екзекуцій, відділ за- } \\
\text { писів та повідомлень та ін. }\end{array}$ \\
\hline 15. & $\begin{array}{l}\text { «Громадський заклад взаємних } \\
\text { страхувань»/«Powszechny Zakład } \\
\text { Ubezpieczeń Wzajemnych» }\end{array}$ & вул. Сінкевича, 25 & - \\
\hline
\end{tabular}

У 20-х pр. ХХ ст. у Дрогобичі було відкрито відділення «Варшавського дискаунтерного банку» («Bank Dyskontny Warszawski»), який вів свою історію ще з 1871 р. як конкурент «Варшавського торгівельного банку». Фундаторами цього банку була родина Епштайнів, а зокрема Мєчислав Епштайн (1833 - †1914). У часі світової кризи банк провадив дуже строгу політику, а тому у 1925 р. постраждав, фактично, найменше. Упродовж 1926 - 1929 рр. банк поступово покинув різноманітні банківські спілки, але незабаром змушений був злитися із «Wiener Boden Credit-Anstalt», яку контролював «Малопольський банк» у Кракові. Після того, як у 1931 р. спілка «Osterreichische Credit-Anstalt» оголосила про своє банкрутство «Варшавський дискаунтерний банк» втратив 80 \% своїх вкладів. І хоча згодом банк розпочав переговори про об'єднання із «Західним банком», після панічного 1931 р. він ніколи вже не досягав колишніх прибутків. Остаточно банк був ліквідований у 1946 р. Від початку свого заснування дрогобицька філія мала можливість користуватися доступом до загальних активів банку у Варшаві, що явно впливало на попит, адже у різний час сума була колосальною. Наприклад, у 1925 р. - 10000000 злотих, а в 1939 р. - 7110000 злотих $[5,98-100]$.

Одним із найуспішніших банків міжвоєнного Дрогобича був «Польський промисловий банк», у будинку котрого принаймні від 1937 р. діяв державний «Скарбовий уряд» («Urząd skarbowy»), який продовжив традицію австрійського промислового банку у цьому ж приміщені. Так, у 1922 - 1923 рр. реконструкцію та консервацію давнього будинку цього банку здійснював відомий львівський архітектор та консерватор Ян Александр Багеньський (25 січня 1883, Сороки - † 12 червня 1967, Львів), який фактично перетворив будинок на той, який ми маємо можливість спостерігати сьогодні (див. фото 1). Так, на думку дослідниці історії архітектури Тетяни Кліменюк, Я. Багеньський втілив однакову методику свого стилю у будинку банку в Дрогобичі, а також у палаці Бельських на вул. Коперника у Львові, кредитній залі Великого Любіня, віллі на вул. Шуха у Варшаві, будинку при вул. Івана Франка у Львові, проекті будинку музею ім. Кресновських у Варшаві та ін. У своїй концепції автор завжди передавав нові стилістичні засоби для відтворення образу. Предметом мистецького інтересу архітектора була система пропорцій і декорацій, при цьому результатом його пошуків завжди була власна інтерпретація класичного порядку із застосуванням пропорцій класичних колон. Врешті архітектор завжди враховував технічні та конструкційні можливості будівлі під час реставраційних робіт $[4,159]$. Найбільші авторитетними мистецькими стилями інтер'єру були комбінації із так званим «другим світлом», коли два чи три яруси із балконами прикрашалися серйозною різьбою і півторакратних нішах, які, підтримувані колонами та балясами, формували єдину структуру. Подібний підхід Я. Багеньський застосував у «Польському промисловому банку» Дрогобича. Тут при реконструкції було застосовано так звану триступеневу композицію фасаду із стислою симетрією та виокремленням центральної частини із колонним портиком цокольного поверху, а також пілястрами такого ж стилю по боках. Завдячуючи цьому підходу відчувається єдиний мистецький ритм архітектора. Вікна будівлі так само виокремлені пілястрами. Кульмінацією архітектурного стилю будинку є балкон і балконна балюстрада, ідентична до балюстрад та балконів палацу Бєльських у Львові [4, 159]. 
У 1938 р. банк діяв під назвою «Кооперативний банк польських ремісників та промисловців»/«Bank Spółdzielczy polskich rękodzielników i przemysłowców», програми котрого передбачали підтримку дрібно та середнього бізнесу, зокрема дрібних ремісників.

У радянський час у приміщенні колишнього промислового банку діяв «Державний банк», 3 історії котрого береглося чимало цікавих документів та фотографій. Так, 14 червня 1970 p. дрогобицьким фотографом тут було зафіксовано кілька робочих моментів працівників цього банку Любов Лазорак та Марії Шатинської. Зокрема, на фотографіях видно внутрішнє устаткування, елементи міжвоєнного інтер’єру реставрованого Я. Багеньським (див. фото № 2-4). Наприкінці 90-х рр. ХХ ст. тут діяв «Укрсоцбанк», а сьогодні цей будинок належить дрогобицькій філії банку «UniCredit Bank», яким успішно керує відомий банкір Ірина Грущак.

У 1925 р. в Дрогобичі було відкрито філію польського «Варшавського банку для торгівлі і промисловості» («Bank dla handlu i przemysłu», колишній «Кредитний банк для торгівлі та промисловості»). У цей час банк був одним із найрозлогіших за своїми розмірами, адже йому належало 90 філій та відділів. Під час інфляції 20 - 30-х рр. ХХ ст. завдяки вдалим діям директора Стефана Бензера, банк уникнув декапіталізації. Певні проблеми у філіях з'явилися у 1924 р., коли гданська фірма з обробки дерева, збанкрутувавши, заборгувала банку $200000 \$$. У 1925 р. банку втягнувся у тривалу судову справу, яка коштувала йому надто дорого, адже тут був замішаний відомий фінансист Войцех Корфанти. Банк перестав функціонувати у 1933 р., у зв’язку із ліквідацією, а його останній капітал у 1931 р. становив 8000000 злотих, що більш ніж у два рази менше за 1925 р. [5, 111-112]

У 1923 р. у Дрогобичі почало функціонувати відділення Акціонерної спілки «Варшавський кредитний банк» («Bank Kredytowy w Warszawie SA»), який був заснований ще у 1916 p. у Варшаві на основі капіталу колишньої «Варшавської кредитної каси». Фактично виникнення банку було пов'язане із визволенням Варшави від російської окупації в часі війни, а також ліквідацією російського реструкційного банківського права. У 1917 р. контроль над банком належав «Польському торговому банку в Познані». Найбільшого удар банк зазнав під час світової економічної кризи, а тому у грудні 1924 р. був об’єднаний із «Варшавським банком для торгівлі та промисловості». Зауважимо, що перед відкриттям філії у Дрогобичі загальний баланс цього банку у Польщі становив 1 млрд. злотих, що завдячувалося діяльності постійного презеса Генрика Барильського [5, 115-116].

Тоді ж (1923) у Дрогобичі було відкрито відділення згадуваного раніше «Польського торгового банку у Познані» («Polski Bank Handlowy SA w Poznaniu»), який, починаючи від 1872 р., займався іпотечними кредитами та короткотерміновими позиками для сільських господарів. Упродовж 1877 - 1934 рр. банком керував Казимир Ганцє. В часі утворення II Речі Посполитої банк мав серйозний політичний вплив на міністерство, врешті у 1919 р. його директора було обрано міністром промисловості і торгівлі Польщі [5, 163-164].

31926 p. «Bank Przemysłowy dla Królestwa Galicji i Lodomerii z Wielkim Księstwem Krakowskim» почав іменуватися як «Polski Bank Przemysiowy w Warszawie». Початково основна мета банку полягала у підтримці розвитку галицького господарства. Також статут банку дозволяв право емісії власних облігацій та промислових цінних паперів. У 1925 р. відділення було відновлене у Стрию, Дрогобичі та Бориславі. Під час світової економічної кризи банк поніс численні втрати, однак завдяки підтримці «FPIK» на суму 7300000 злотих залишився на ринку фінансового бізнесу. Однією з умов підтримки було злиття активів із «Њ1№skim Bankiem Przemysłowym». Після того, як у 1926 р. банк уклав угоду із французьким банком «Societe Financiere de Paris», 85 \% активів «Варшавського промислового банку» перейшло до рук нафтового концерну «Devildera». Відтак філія банку в Дрогобичі почала працювати між польським нафтовим промислом та французьким інвестором. У цей час до ради банку увійшли: Делер Камбацере, П’єр Бонкон і П’єр Лакалле, а поляк Мартін Шарський почав виконувати функції презеса Наглядової ради банку, при цьому посаду директора відтепер обіймав француз Георг Ках’єр. Під час кризи у 1931 р. французькі активи серйозно занепали, відтак філія у Дрогобичі теж частково ослабилася, щоправда на рівні країни банк і надалі посідав почесне четверте місце серед усіх банків. У жовтні 1931 р. банку було 
перейменовано на Акціонерну спілку «Експортний банк». Щоправда, після того, як у 1932 р. банк оголосив про власні витрати на колосальну суму 18900000 злотих, у 1933 р. банку був поставлений у програму ліквідації [5, 167-168].

У 1922 р. в Дрогобичі також діяла філія Акціонерної спілки «Універсальний кредитний банк у Львові» («Powszechny Bank Kredytowy SA we Lwowie»), який вів свою історію від 1910 р., коли він засновувався під назвою «Galicyjski Ludowy Bank dla Rolnictwa i Handlu». Якщо у період правління Габсбургів банк був пов'язаний із австрійським міністром промисловості Галичини, то у міжвоєнний час сенаторові II Речі Посполитої Владиславу Длугошу. Стрімкий розвиток банку був зупинений подіями Першої світової війни. У 1919 р. банк отримав нову назву «Універсальний кредитний банк», а в 1922 р. основний офіс переїхав до Парижа, де було усталено назву «Banque des Pays de 1'Europe Centrale». Нова інституція на 40 \% була власністю Австрії, а на 60 \% - французькою. Переживши кризу 1925 р., і завдяки короткотерміновим кредитам та заставам на нерухомість у 1926 р. був перенесений до Варшави. Під час «Великої депресії» на початку 1930-х рр. банк зумів утриматися серед шести найпотужніших приватних банків Польщі. Станом на 1928 р. банку належав акційний капітал на суму 5000000 злотих, при цьому до 1939 р. його презесом був Адам Крижановський, а директором - Еміль Грабшайд [5, 171].

30 червня 1930 р. власну філію у Дрогобичі відкрила Акціонерна спілка «Універсальний Федеральний банк Польщі у Львові» («Powszechny Bank Związkowy w Polsce SA we Lwowie»), центр котрого у 1930 р. переїхав до Варшави, а тому банк почав іменуватися не львівським, а варшавським. Дрогобицька філія була третьою за розмірами після Бєльська і Цешина, навіть Краківське відділення обіймало четверту позицію. Будучи фактично гілкою потужного бельгійського банківського концерну «Societe Generale de Belgique»у період кризи 1925 р., навіть при своєму невеликому приватному капіталу банк практично не постраждав на відміну від інших банків. Основну роль у цьому відіграла програма уникнення великих вкладень. Станом на 1928 р. акціонерний капітал банку становив у Польщі 8000000 злотих. У березні 1935 р. із банком був пов'язаний серйозний кримінальний скандал, адже вся жовта преса повідомляла про самовбивство віце-директора і прокурента філії «Універсального Федерального банку Польщі» пана Арнольда Пастора, що з невідомих причин вистрілив із револьвера собі у скроню. Він полишив після себе вдову Ельзабет Пастор із дому Вайнштайн, яка, однак, зовсім не прокоментувала подій. Цілком ймовірно, ситуація була пов'язана із діяльністю банку [7]. До 1940 р. директором банку був Вацлав Фаянс, а презесом - Владислав Стецслович. Банк було ліквідовано у 1946 р., адже радянська система не передбачала існування приватних структур [5, 172].

Варто зауважити, що в період Другої Світової війни (1941 - 1945) одним із небагатьох банків, який зумів втриматися у справі в період різних окупаційних режимів, був «Польський емісійний банк», заснований під час німецької окупації під назвою «Emissionsbank in Polen. Zweigniederlassung Drohobycz», який офіційно був закритий в Дрогобичі у 1945 р. [1]

Висновки. Таким чином більшість банків, що діяли в міжвоєнний період у Дрогобичі, своїм корінням сягають у добу Австро-Угорщини, будучи тісно пов'язаними із європейськими кредитними системами. Водночас принаймні три будинки давніх дрогобицьких банків «Австро-Угорського» (сучасна Податкова інспекція Дрогобича), «Авансового Товариства» (сучасний «Ощадбанк») та «Промислового Банку» (сучасний «UniCredit Bank») за всю свою історію не змінили цільового призначення, виконуючи й сьогодні головну чи традиційну функцію, пов'язану із оберіганням людських коштів, прибутком, а також найрізноманітнішими кредитними програмами сприянню бізнесу та культурно-освітніх програм. 3 іншого боку, понад столітня традиція ведення фінансових справ у цих давніх банківських приміщеннях сьогодні все ж утілює надію на сповнення заповітної мрії кожного клієнта, у якій гроші $€$ благом лише тоді, коли служать людині, а не навпаки. 


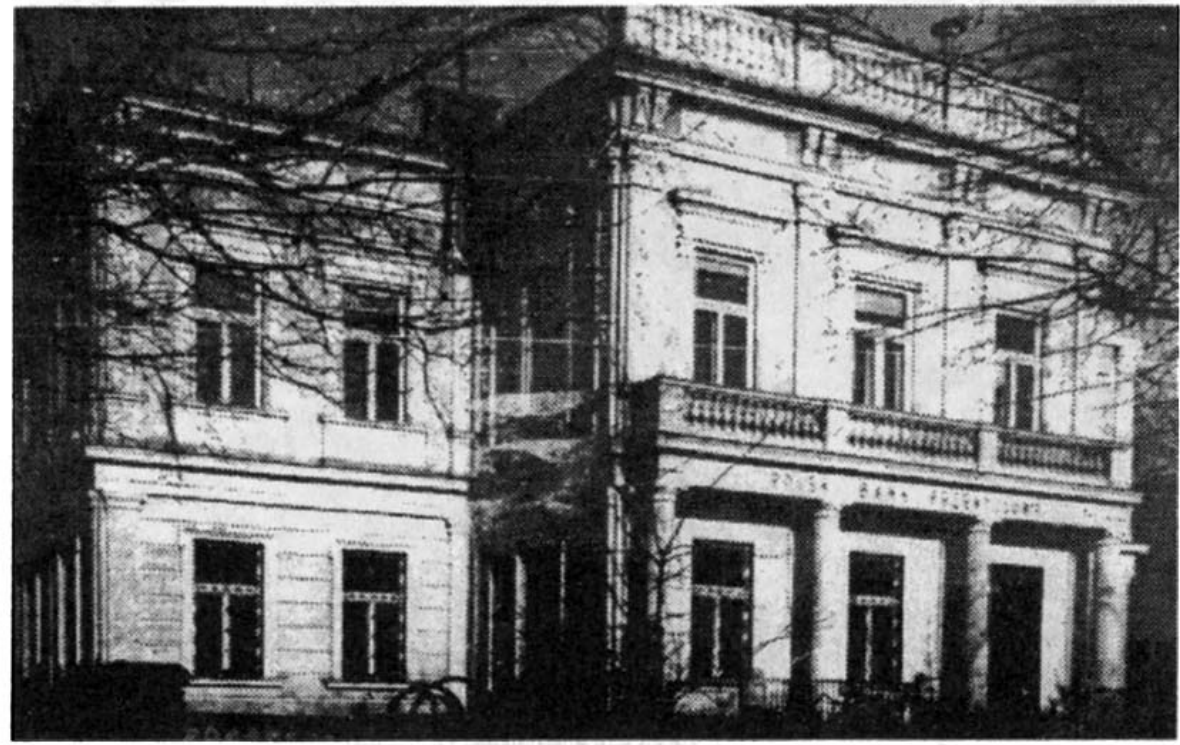

\section{Drobobycz, Polski Bank Przemyslouy. Rekonstrukcja 1922-1923 r. 7. Drobobycz. Reconstruction of the Polish Industrial Bank, 1922-1923}

\section{СПИСОК ВИКОРИСТАНИХ ДЖЕРЕЛ ТА ЛІТЕРАТУРИ}

1. Archiwum akt nowych. Informator o zasobie archiwalnym (stan na dzień 31.III. 2005 r.) / Opracował Edward Kołodziej. - Warszawa, 2005. - 390 s.

2. Bank dla Handlu i Przemysłu w Warszawie // Sztuka i artysta. Malarstwo. Rzeżba. Zdobnictwo. Kolekcjonerstwo. - R. I. - № 1. - Warszawa, 1924. - 119 s.

3. Ben-Joseph M. Adversities of Autonomy. Bank Krajowy Królestwa Galicyi i Lodomeryi and the Politics of Credit in Galicia / M. Ben-Joseph . - Kraków, 1999. - 128 p.

4. Klimeniuk T. Jan Bagieński - architekt i konserwator / T. Klimeniuk // Ochrona Zabytków. - 1993. 46/2 (181). - $268 \mathrm{~s}$.

5. Morawski W. Słownik Historyczny Bankowości Polskiej do 1939 Roku / W. Morawski. - Warszawa, 1998. $-180 \mathrm{~s}$.

6. Plan miasta Drohobycza 1925 - 1939 // Карти міст. План міста Дрогобича. Офіційний сайт Центру міської історії Центрально-Східної Європи. - [Електронний ресурс]. - Режим доступу: http://www.lvivcenter. org/uk/umd/map/?ci_mapid=144

7. Somobójstwo prokurenta // Śląski kurjer poranny: dziennik niezależny polityczno-społeczno-gospodarczy, poświęcony obronie świata pracy. - № 30. - R. 1. - S. 3.

8. Spis abonentów sieci telefonicznych Państwowych i Koncesjonowanych w Polsce (z wyjątkiem m. st. Warszawy) 1932/1933. - Warszawa, 1932. - 705 s.

9. Spis abonentów sieci telefonicznych Państwowych i Koncesjonowanych w Polsce (z wyjątkiem m. st. Warszawy) 1938. - Warszawa, 1938. - $850 \mathrm{~s}$.

10. Spis rachunków żyrowych w Polskiej Krajowej Kasie Pożyczkowej w Warszawie i jej Oddziałach. Stan z dniem 30 października 1921 r. - Warszawa, 1921. - 150 s.

11. Statut Banku Krajowego Królestwa Galicyi i Lodomeryi z Wielkiem Księstwem Krakowskiem: z dodatkiem zawierającym: Ustawę państwową z dnia 21. czerwca 1882 (Dz.u.p. Nr. 81 z r. 1882) i Obwieszczenia c.k. Prezydyum Namiestnictwa w dzienniku ustaw i rozporządzeń krajowych, dotyczące zmian statutu i uchwał Sejmowych w sprawie poręki kraju za poszczególne zobowiązania bankowe). - Bank Krajowy, 1908. - 54 s.

12. Wyłuskane z pamięci. Przeżycia wojenne Jerzego Marii Pileckiego / Opracowanie redakcyjne Danuta Dziwdzic. - Wrocław, 2013. - 178 s.

Стаття надійшла до редакції 24.09.2017 p. 